Article

\title{
Thermal Stability, Hardness, and Corrosion Behavior of the Nickel-Ruthenium-Phosphorus Sputtering Coatings
}

\author{
Yu-Cheng Hsiao and Fan-Bean $\mathrm{Wu}$ * \\ Department of Materials Science and Engineering, National United University, Miaoli 36003, Taiwan; \\ fanbeanwu@gmail.com \\ * Correspondence: fbwu@nuu.edu.tw; Tel.: +886-37-382232
}

Received: 23 July 2020; Accepted: 11 August 2020; Published: 13 August 2020

\begin{abstract}
Nickel-ruthenium-phosphorus, Ni-Ru-P, alloy coatings were fabricated by magnetron dual-gun co-sputtering from Ni-P alloy and Ru source targets. The composition variation and related microstructure evolution of the coatings were manipulated by the input power modulation. The as-prepared Ni-Ru-P alloy coatings with a Ru content less than 12.2 at.\% are amorphous/nanocrystalline, while that with a high Ru content of 52.7 at.\% shows a feature of crystallized $\mathrm{Ni}, \mathrm{Ru}$, and $\mathrm{Ru}_{2} \mathrm{P}$ mixed phases in the as-deposited state. The crystallized phases for high $\mathrm{Ru}$ content $\mathrm{Ni}-\mathrm{Ru}-\mathrm{P}$ coatings are stable against annealing process up to $600{ }^{\circ} \mathrm{C}$. By contrast, the amorphous/nanocrystalline $\mathrm{Ni}-\mathrm{Ru}-\mathrm{P}$ thin films withstand a heat-treated temperature up to $475^{\circ} \mathrm{C}$ and then transform into $\mathrm{Ni}(\mathrm{Ru})$ and $\mathrm{Ni}_{\mathrm{x}} \mathrm{P}_{\mathrm{y}}$ crystallized phases at an annealing temperature over $500{ }^{\circ} \mathrm{C}$. The surface hardness of the Ni-Ru-P films ranges from 7.2 to $12.1 \mathrm{GPa}$ and increases with the Ru content and the annealing temperatures. A highest surface hardness is found for the $550{ }^{\circ} \mathrm{C}$ annealed Ni-Ru-P with a high Ru content of 52.7 at. $\%$. The $E_{\text {corr }}$ values of the heat-treated amorphous/nanocrystalline $\mathrm{Ni}-\mathrm{Ru}-\mathrm{P}$ coatings become more negative, while with a high $\mathrm{Ru}$ content over 27.3 at. \% the Ni-Ru-P films show more negative $E_{\text {corr }}$ values after annealing process. The pitting corrosion feature is observed for the amorphous/nanocrystalline Ni-Ru-P coatings when tested in a $3.5 \mathrm{M} \mathrm{NaCl}$ solution. Severer pitting corrosion is found for the $550{ }^{\circ} \mathrm{C}$ annealed $\mathrm{Ni}-\mathrm{Ru}-\mathrm{P}$ coatings. The development of $\mathrm{Ni}(\mathrm{Ru})$ and $\mathrm{Ni}_{x} \mathrm{P}_{y}$ crystallized phases during annealing is responsible for the degeneration of corrosion resistance.
\end{abstract}

Keywords: Ni-Ru-P; sputtering; annealing; corrosion

\section{Introduction}

Nickel-phosphorus (Ni-P) coating has been frequently adopted as a hard alloy coating due to corrosion resistance, high hardness and toughness, wear resistance, etc. [1-6]. The Ni-P alloy coatings are frequently deposited through wet chemical methods, including electroplating or electroless plating. Generally speaking, the electroplated or electroless Ni-P coatings possess a supersaturated microstructure feature in as-deposited and can be strengthened by the crystallization of $\mathrm{Ni}$ and the precipitation of Ni-P crystallites with appropriate heat treatment. However, the low crystallization temperature of approximately $350^{\circ} \mathrm{C}$ of the Ni-P coatings is critical for high-temperature applications and further fields of use [7]. The introduction of the third elements and compounds, including $\mathrm{Al}$ [8], $\mathrm{Cr}$ [9], $\mathrm{Mo}$ [10], $\mathrm{Cu}$ [11-13], $\mathrm{Al}_{2} \mathrm{O}_{3}$ [14,15], CNTs [16,17], etc., are frequently proposed to further enhance its mechanical, thermal, and chemical properties. For instance, the thermal stability of the Ni-P layer could be improved by the introduction of a third element with high melting point like $W[18,19]$. The addition of $\mathrm{W}$ atoms, even at a low level of 3 at.\%, has a significant effect on promoting the 
thermal stability of the ternary $\mathrm{Ni}-\mathrm{W}-\mathrm{P}$ films [19]. The precipitation of $\mathrm{Ni}_{3} \mathrm{P}$ phase, which takes place at around $350{ }^{\circ} \mathrm{C}$ in a binary $\mathrm{Ni}-\mathrm{P}$ alloy films, is postponed up to $450{ }^{\circ} \mathrm{C}$ due to $\mathrm{W}$ incorporation. The codeposition of $\mathrm{W}$ atoms also induce the $\mathrm{W}$ solid-solutioning in Ni crystalline phase, i.e., $\mathrm{Ni}(\mathrm{W})$ matrix, which further boosts the surface hardness over $10 \mathrm{GPa}$. The increase in thermal stability and mechanical properties of the binary Ni-P layer can be achieved by the addition of $\mathrm{Al}$ element to form a ternary Ni-Al-P film [8]. A two-stage strengthening by $\mathrm{Ni}_{3} \mathrm{P}$ and $\mathrm{Ni}_{x} \mathrm{Al}_{y}$ precipitations at 400 and $500{ }^{\circ} \mathrm{C}$, respectively, is manifested. The hardness of the Ni-Al-P films is pushed up from 7.0, 9.5, to $11.0 \mathrm{GPa}$ as annealed at 400,500 , to $550^{\circ} \mathrm{C}$. Marzo and coworkers [20] produced Cr-coplated Ni-P film and found an enlarged polarization resistance for the Ni-P-Cr film. However, the coplating of ternary Ni-P-based layers needs complex solution design. Thus, an alternative method using physical vacuum deposition is proposed $[8,12,19,21,22]$. The co-deposition of a third element into Ni-P alloy through the sputtering technique has been successfully adopted in Ni-P-based alloy coatings with good composition control. Since the phase evolution of the Ni-P-based thin film is sensitive to addition element content and thermal history, the control on third element concentration and annealing process are thus critical to the related properties. To enhance the thermal stability and corrosion resistance, various kind of material systems have been applied into Ni-P-based coatings as described above. The Ru element has been studied as a promising catalyst for hydrogen evolution reaction due to its small overpotential as compared to commercial Pt material [23]. The RuCo dispersion on Ru film has been proved as an effective catalyst for the hydrogenation of $\mathrm{CO}_{2}$ [24], meaning that $\mathrm{Ru}$ can be produced in a fashion of alloy film to provide specific functions. However, reports on the feasibility of introduction of noble metals into the Ni-P deposits, which are characterized by their high thermal and chemical stability, are limited. In present case, the ruthenium is introduced as the additive element to $\mathrm{Ni}-\mathrm{Ru}-\mathrm{P}$ alloy thin films based on its high melting point, excellent chemical inertness and thermal stability. The ternary Ni-Ru-P coating is fabricated by the co-sputtering technique with input power control on metallic targets as sputtering sources. The microstructure feature, thermal stability, hardness and elastic modulus, and corrosion resistance of the $\mathrm{Ni}-\mathrm{Ru}-\mathrm{P}$ coatings with various $\mathrm{Ru}$ contents are analyzed. The effect of phase transformation due to annealing on thermal stability, surface hardness, and corrosion characteristics are discussed.

\section{Materials and Methods}

The Ni-Ru-P coatings were deposited through magnetron dual-gun co-sputtering technique on AISI 420 stainless steel substrates. The $\mathrm{Ni}_{75} \mathrm{P}_{25}$ compound and pure Ru targets both of 50.8 and $6.25 \mathrm{~mm}$ in diameter and thickness, respectively, were employed as sputtering sources. Two guns with a radio frequency magnetron sputtering, RFMS, input were adopted. Prior to deposition, the vacuum chamber was evacuated down to $4.0 \times 10^{-4} \mathrm{~Pa}$ followed by the inlet of high purity argon gas to a working pressure of $3.7 \times 10^{-1} \mathrm{~Pa}$. The targets were pre-sputtered for $10 \mathrm{~min}$ in order to clean the target surfaces followed by the deposition process. During sputtering, the input power for Ru was tuned from 15 to $100 \mathrm{~W}$ with a fixed power at $100 \mathrm{~W}$ on the Ni-P compound target. The deposition time and substrate temperature were set as $2 \mathrm{~h}$ and $200{ }^{\circ} \mathrm{C}$, respectively. The thickness for all coatings was controlled around $1 \mu \mathrm{m}$ for reliable characterizations. To evaluate the coating structural stability under thermal process, the coated samples were annealed from 350 to $600{ }^{\circ} \mathrm{C}$ in a vacuum environment at $4.0 \times 10^{-4} \mathrm{~Pa}$ level for $3 \mathrm{~h}$ and then were furnace cooled. The chemical composition of the Ni-Ru-P coatings was evaluated with a field-emission electron probe microanalyzer (FE-EPMA, JXA-iHP200F, JEOL, Tokyo, Japan). The phases of sputtered coatings in as-deposited and annealed states were analyzed by a conventional X-ray diffractometer (XRD, TTRAX III, Rigaku, Tokyo, Japan). The surface images of the coatings were observed with a field-emission scanning electron microscope (FE-SEM, JEOL, JSM-6700, Tokyo, Japan). The coating thickness was also measured from the cross-sectional SEM image. The surface hardness and elastic modulus of various $\mathrm{Ni}-\mathrm{Ru}-\mathrm{P}$ coatings were examined using a nano-indentation tester (Nano Hardness Tester, CSM Instrument, Needham Heights, MA, USA) equipped with a Berkovich three-faced pyramidal diamond indenter under a test load of $3 \mathrm{mN}$. 
At least five indents were made, measured and averaged on a statistical basis. The electrochemical polarization curve was generated by an electrochemical workstation (Jiehan-5000, Jiehan, Taiwan) with a build-in software for corrosion potential and current density calculation. An electrochemical cell with the $3.5 \mathrm{M} \mathrm{NaCl}$ solution maintained at $25{ }^{\circ} \mathrm{C}$ was used. A Pt counter electrode and a saturated calomel electrode (SCE) reference electrode were employed. The samples were immersed in the testing solution for $30 \mathrm{~min}$ to stabilize the open circuit potential (OCP). The scanning range was set form -0.25 to $+0.25 \mathrm{~V}$ according to the OCP. Coating morphologies after chemical attack were observed via FE-SEM, as mentioned above.

\section{Results and Discussion}

\subsection{Microstructure and Thermal Stability}

The sputtered ternary $\mathrm{Ni}-\mathrm{Ru}-\mathrm{P}$ coatings are fabricated by the dual-gun sputtering system. At a fixed power of $100 \mathrm{~W}$ for the $\mathrm{Ni}_{75} \mathrm{P}_{25}$ target, the $\mathrm{Ru}$ contents of the $\mathrm{Ni}-\mathrm{Ru}-\mathrm{P}$ coatings are from 3.3 to 52.7 at.\% under an input power range from 15 to $100 \mathrm{~W}$, as listed in Table 1 . The Ni and P concentration decrease systematically with the contents of Ru element in the alloy coatings. The Ni to P ratio in each $\mathrm{Ni}-\mathrm{Ru}-\mathrm{P}$ coating is also calculated for reference. The Ni/P ratios are around $4.1-4.6$, regardless of the variation in $\mathrm{Ru}$ content in the $\mathrm{Ni}-\mathrm{Ru}-\mathrm{P}$ films. This indicates the supplies of the $\mathrm{Ni}$ and $\mathrm{P}$ from the $\mathrm{Ni}_{75} \mathrm{P}_{25}$ target are stable during co-sputtering process.

Table 1. The deposition conditions and composition of the sputtered Ni-Ru-P coatings.

\begin{tabular}{|c|c|c|c|c|c|c|c|}
\hline \multirow{2}{*}{$\begin{array}{c}\text { Coating } \\
\text { Designation }\end{array}$} & \multicolumn{2}{|c|}{ Input Power (W) } & \multirow{2}{*}{$\begin{array}{c}\text { Thickness } \\
(\mu \mathrm{m})\end{array}$} & \multicolumn{3}{|c|}{ Composition (at.\%) } & \multirow{2}{*}{$\mathbf{N i} / \mathbf{P}$} \\
\hline & $\mathrm{Ni}_{75} \mathbf{P}_{25}$ & $\mathbf{R u}$ & & $\mathbf{N i}$ & $\mathbf{P}$ & $\mathbf{R u}$ & \\
\hline $\mathrm{A}, \mathrm{Ni}_{78.9} \mathrm{Ru}_{3.3} \mathrm{P}_{17.8}$ & 100 & 15 & $0.94 \pm 0.08$ & $78.9 \pm 0.3$ & $17.8 \pm 0.3$ & $3.3 \pm 0.1$ & 4.4 \\
\hline $\mathrm{B}, \mathrm{Ni}_{72.0} \mathrm{Ru}_{12.2} \mathrm{P}_{15.8}$ & 100 & 25 & $0.94 \pm 0.10$ & $72.0 \pm 0.2$ & $15.8 \pm 0.2$ & $12.2 \pm 0.2$ & 4.6 \\
\hline C, $\mathrm{Ni}_{58.5} \mathrm{Ru}_{27.3} \mathrm{P}_{14.2}$ & 100 & 50 & $0.85 \pm 0.11$ & $58.5 \pm 0.2$ & $14.2 \pm 0.1$ & $27.3 \pm 0.3$ & 4.1 \\
\hline $\mathrm{D}, \mathrm{Ni}_{38.6} \mathrm{Ru}_{52.7} \mathrm{P}_{8.7}$ & 100 & 100 & $1.30 \pm 0.15$ & $38.6 \pm 0.9$ & $8.7 \pm 0.2$ & $52.7 \pm 0.8$ & 4.4 \\
\hline
\end{tabular}

The phase evolution of the $\mathrm{Ni}-\mathrm{Ru}-\mathrm{P}$ coatings under various annealing temperatures is investigated through X-ray diffraction technique to evaluate the thermal stability of the alloy thin films. As plotted in Figure 1, for coatings with Ru contents less than 27.3 at.\%, i.e., A, B, and C, the $200{ }^{\circ} \mathrm{C}$ as-deposited films show an amorphous/nanocrystalline feature, which is characterized by a representative broadened peak. The $2 \theta$ peak position is around $44.6^{\circ}$, where a Ni (111) orientation is suggested. Since Ni, $\mathrm{P}$ and $\mathrm{Ru}$ are co-sputtered, an amorphous/nanocrystaline $\mathrm{Ni}$ matrix with $\mathrm{Ru}$ and $\mathrm{P}$ incorporated microstructure is expected. With the increase of annealing temperature, the amorphous/nanocrystaline microstructure develops into the $\mathrm{Ni}$ and $\mathrm{Ni}_{x} \mathrm{P}_{y}$ phases, including $\mathrm{Ni}_{3} \mathrm{P}, \mathrm{Ni}_{5} \mathrm{P}_{2}$, and $\mathrm{Ni}_{12} \mathrm{P}_{5}$, as shown in Figure 1. It is noted that there is no $\mathrm{Ru}$ related diffraction peaks found in the patterns. In recent research of Shin [25], Ru-P alloy films remained an amorphous feature under vacuum annealing up to $500{ }^{\circ} \mathrm{C}$. As a consequence, the $\mathrm{Ni}(\mathrm{Ru})$ with $\mathrm{Ni}_{x} \mathrm{P}_{y}$ intermetallic phases are confirmed for the $\mathrm{Ni}_{72.0} \mathrm{Ru}_{12.2} \mathrm{P}_{15.8}$ coatings.

Discrepancy in phase transformation phenomenon is found for the Ni-Ru-P films with high $\mathrm{Ru}$ content of 52.7 at.\%, as depicted in Figure 2. According to the phase diagrams [26], the Ni, Ru, and $\mathrm{Ru}_{2} \mathrm{P}$ are identified for the $\mathrm{Ni}_{38.6} \mathrm{Ru}_{52.7} \mathrm{P}_{8.7}$ coatings under various annealing temperatures up to $600{ }^{\circ} \mathrm{C}$. This implies the $\mathrm{Ni}, \mathrm{Ru}$, and $\mathrm{Ru}_{2} \mathrm{P}$ phases are thermally stable against heat treatments. It is argued that the multiphase feature which forms even under $200{ }^{\circ} \mathrm{C}$ as-deposited condition is attributed to the relative high power co-sputtering, i.e., $100 \mathrm{~W}$ for both targets. On the other hand, the P element depletes through the formation of $\mathrm{Ru}_{2} \mathrm{P}$ with $\mathrm{Ru}$ during film deposition. No further $\mathrm{P}$ can be used to form $\mathrm{Ni}_{x} \mathrm{P}_{y}$ compounds with $\mathrm{Ni}$ at elevated temperature during annealing. Stable and mixed $\mathrm{Ni}$, $\mathrm{Ru}$, and $\mathrm{Ru}_{2} \mathrm{P}$ phases are consequently observed for the $\mathrm{Ni}_{38.6} \mathrm{Ru}_{52.7} \mathrm{P}_{8.7}$ coatings. Figure 3 shows the plane view FE-SEM images of the as-deposited $\mathrm{B}, \mathrm{Ni}_{72.0} \mathrm{Ru}_{12.2} \mathrm{P}_{15.8}$ and $\mathrm{D}, \mathrm{Ni}_{38.6} \mathrm{Ru}_{52.7} \mathrm{P}_{8.7}$ coatings. Figure $3 b$ exhibits a smooth surface condition while significant crystallized morphology with many 
tiny mounds is observed for the $\mathrm{Ni}_{38.6} \mathrm{Ru}_{52.7} \mathrm{P}_{8.7}$ film. Such a difference is again attributed to the amorphous/nanocrystalline and mixed phase microstructures for low and high Ru content Ni-Ru-P coatings, respectively.

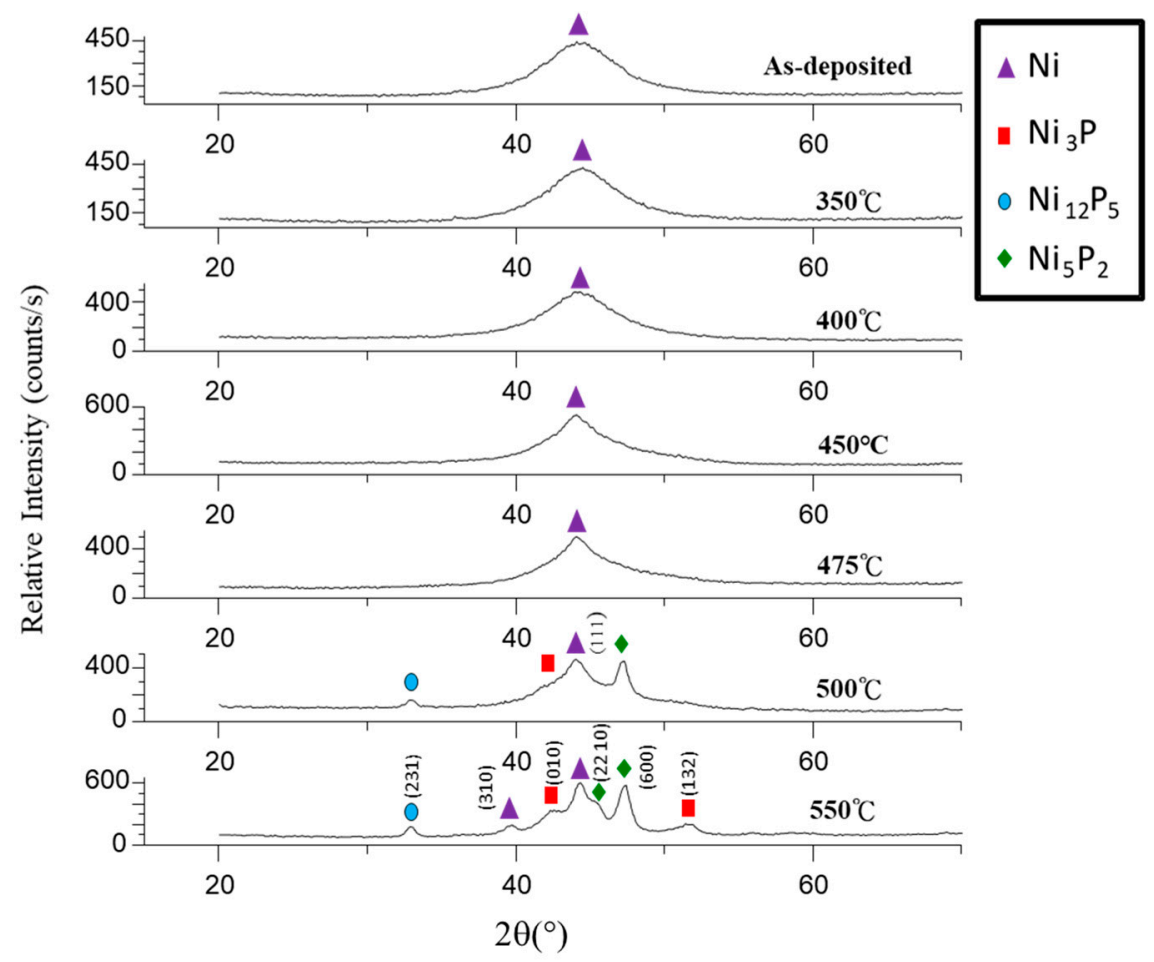

Figure 1. X-ray diffraction patterns of $\mathrm{B}, \mathrm{Ni}_{72.0} \mathrm{Ru}_{12.2} \mathrm{P}_{15.8}$ coatings annealed at various temperatures for $3 \mathrm{~h}$.

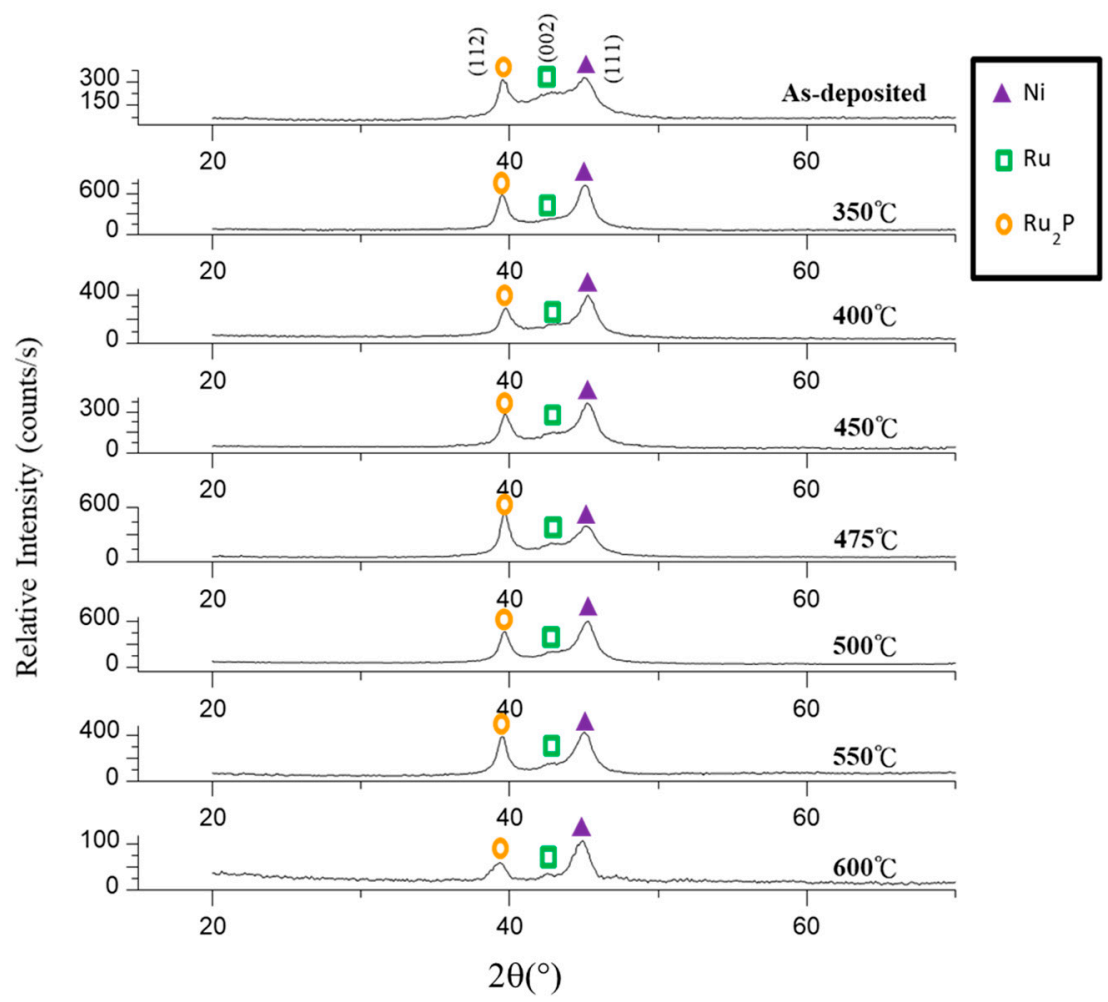

Figure 2. X-ray diffraction patterns of $\mathrm{D}, \mathrm{Ni}_{38.6} \mathrm{Ru}_{52.7} \mathrm{P}_{8.7}$ coatings annealed at various temperatures for $3 \mathrm{~h}$. 


\subsection{Surface Hardness and Elastic Modulus}

Table 2 depicts the surface hardness of various Ni-Ru-P coatings evaluated through nanoindentation technique. The hardness and elastic modulus for the as-fabricated and annealed samples are listed for comparison. For the as-deposited films, the surface hardness increases simply from 7.2 to $10.4 \mathrm{GPa}$ with the addition of $\mathrm{Ru}$ from 3.3 to 52.7 at.\%. Obviously the promotion in hardness is attributed by the Ru addition amounts. After heat treatment, the hardness of each film increases as compared to those in the as-deposited state. The hardness increases with annealing temperatures. For instance, the hardness of sample $\mathrm{B}, \mathrm{Ni}_{72.0} \mathrm{Ru}_{12.2} \mathrm{P}_{15.8}$, is enhanced from 7.2 to 8.9 and $9.5 \mathrm{GPa}$ as annealing temperatures of 475 and $550{ }^{\circ} \mathrm{C}$ are applied, respectively. Sample $\mathrm{C}$ also shows a hardness increase with respect to temperature in the similar manner. The phase transformation from amorphous to nanocrystalline Ni matrix with $\mathrm{Ni}_{x} \mathrm{P}_{y}$ precipitation, as indicated in Figure 2, is the key to such strengthening. For the case of sample $\mathrm{D}, \mathrm{Ni}_{38.6} \mathrm{Ru}_{52.7} \mathrm{P}_{8.7}$, a mixed phase feature is generated in the as-deposited state, leading to a higher hardness value, as compared to those of samples A, B, and C. After annealing at 475 and $550{ }^{\circ} \mathrm{C}$, the slight development of the mixed crystalline phases causes the increase from 10.4, to 11.1 and $12.1 \mathrm{GPa}$, respectively. It should be noted that in our previous research works on Ni-Al-P [8] and Ni-W-P coatings [7,19,21], the addition of the third elements, $\mathrm{Al}$ or $\mathrm{W}$, is beneficial in promoting the thermal stability and hardness of the Ni-P-based ternary alloy coatings. The promotion is mainly due to the delay of $\mathrm{Ni}$ recrystallization and $\mathrm{Ni}_{3} \mathrm{P}$ precipitation toward higher temperatures. Moreover, the third elements, $\mathrm{Al}$ and $\mathrm{W}$, dissolve into Ni crystalline phases and strengthen the Ni-P-based alloy coatings. In present case, it is argued that the addition of Ru below 27.3 at.\% shows an identical strengthening effect on thermal stability and hardness of the $\mathrm{Ni}-\mathrm{Ru}-\mathrm{P}$ alloys. In addition, the elastic modulus shows the similar trend with composition and heat treatment process. For example, the as-deposited $\mathrm{Ni}-\mathrm{Ru}-\mathrm{P}$ films possess an elastic modulus lower than 190.9 GPa as Ru content is less than 27.2 at.\%, while a highest elastic modulus of $210.3 \mathrm{GPa}$ is measured for the $\mathrm{Ni}_{38.6} \mathrm{Ru}_{52.7} \mathrm{P}_{8.7}$ film. With the heat treatments under 475 and $550{ }^{\circ} \mathrm{C}$, the phase evolution of the $\mathrm{Ni}-\mathrm{Ru}-\mathrm{P}$ coatings is responsible for the gradual increase in elastic modulus for each $\mathrm{Ni}-\mathrm{Ru}-\mathrm{P}$ deposit.
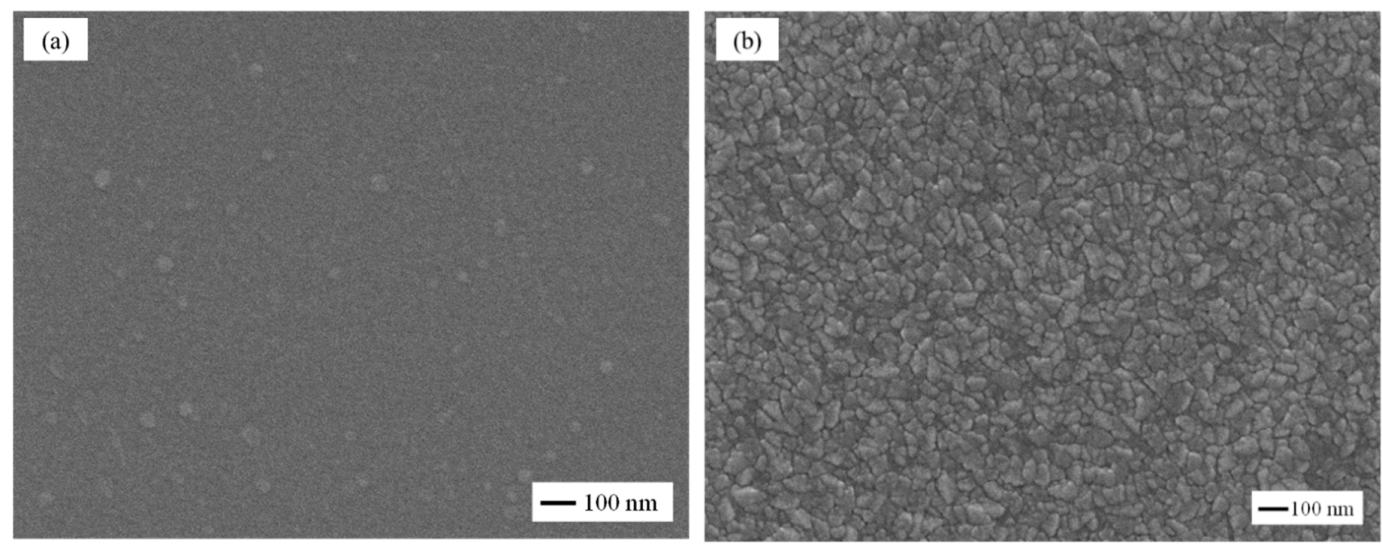

Figure 3. The plane view field-emission scanning electron microscope (FE-SEM) images of the as-deposited (a) B, $\mathrm{Ni}_{72.0} \mathrm{Ru}_{12.2} \mathrm{P}_{15.8}$ and (b) $\mathrm{D}, \mathrm{Ni}_{38.6} \mathrm{Ru}_{52.7} \mathrm{P}_{8.7}$ coatings.

Table 2. The surface hardness and elastic modulus of the Ni-Ru-P coatings in as-deposited and annealed states.

\begin{tabular}{cccc}
\hline Coating Systems & Process Condition & Hardness (GPa) & Elastic Modulus (GPa) \\
\hline $\mathrm{A}, \mathrm{Ni}_{78.9} \mathrm{Ru}_{3.3} \mathrm{P}_{17.8}$ & $200{ }^{\circ} \mathrm{C}$ as-deposited & $7.2 \pm 0.1$ & $161.8 \pm 9.5$ \\
\hline & $200{ }^{\circ} \mathrm{C}$ as-deposited & $7.2 \pm 0.4$ & $138.3 \pm 6.6$ \\
$\mathrm{~B}, \mathrm{Ni}_{72.0} \mathrm{Ru}_{12.2} \mathrm{P}_{15.8}$ & $475^{\circ} \mathrm{C}$ annealed & $8.9 \pm 0.5$ & $164.9 \pm 5.8$ \\
& $550{ }^{\circ} \mathrm{C}$ annealed & $9.5 \pm 0.2$ & $201.1 \pm 11.1$ \\
\hline
\end{tabular}


Table 2. Cont.

\begin{tabular}{cccc}
\hline Coating Systems & Process Condition & Hardness (GPa) & Elastic Modulus (GPa) \\
\hline & $200{ }^{\circ} \mathrm{C}$ as-deposited & $8.1 \pm 0.4$ & $190.9 \pm 0.4$ \\
$\mathrm{C}, \mathrm{Ni}_{58.5} \mathrm{Ru}_{27.3} \mathrm{P}_{14.2}$ & $475^{\circ} \mathrm{C}$ annealed & $9.1 \pm 0.4$ & $189.4 \pm 11.3$ \\
& $550^{\circ} \mathrm{C}$ annealed & $9.5 \pm 0.3$ & $211.4 \pm 8.4$ \\
\hline & $200{ }^{\circ} \mathrm{C}$ as-deposited & $10.4 \pm 0.2$ & $210.3 \pm 1.6$ \\
$\mathrm{D}, \mathrm{Ni}_{38.6} \mathrm{Ru}_{52.7} \mathrm{P}_{8.7}$ & $475^{\circ} \mathrm{C}$ annealed & $11.1 \pm 0.7$ & $221.9 \pm 14.7$ \\
& $550^{\circ} \mathrm{C}$ annealed & $12.1 \pm 0.6$ & $246.2 \pm 18.7$ \\
\hline
\end{tabular}

\subsection{Corrosion Resistance Evaluation}

The electrochemical behavior of the Ni-Ru-P coatings in both as-deposited and annealed states were analyzed through potentiodynamic polarization test and corroded surface images. Figure 4 indicates the polarization curves of the as-deposited $\mathrm{Ni}-\mathrm{Ru}-\mathrm{P}$ coatings. The calculated $E_{\text {corr }}$ and $I_{\text {corr }}$ values for the all the coatings are summarized in Table 3. The A, Ni ${ }_{78.9} \mathrm{Ru}_{3.3} \mathrm{P}_{17.8}$ and $\mathrm{B}, \mathrm{Ni}_{72.0} \mathrm{Ru}_{12.2} \mathrm{P}_{15.8}$ coatings show relatively higher $E_{\text {corr }}$ values than $\mathrm{C}, \mathrm{Ni}_{58.5} \mathrm{Ru}_{27.3} \mathrm{P}_{14.2}$ film in the as-deposited condition.

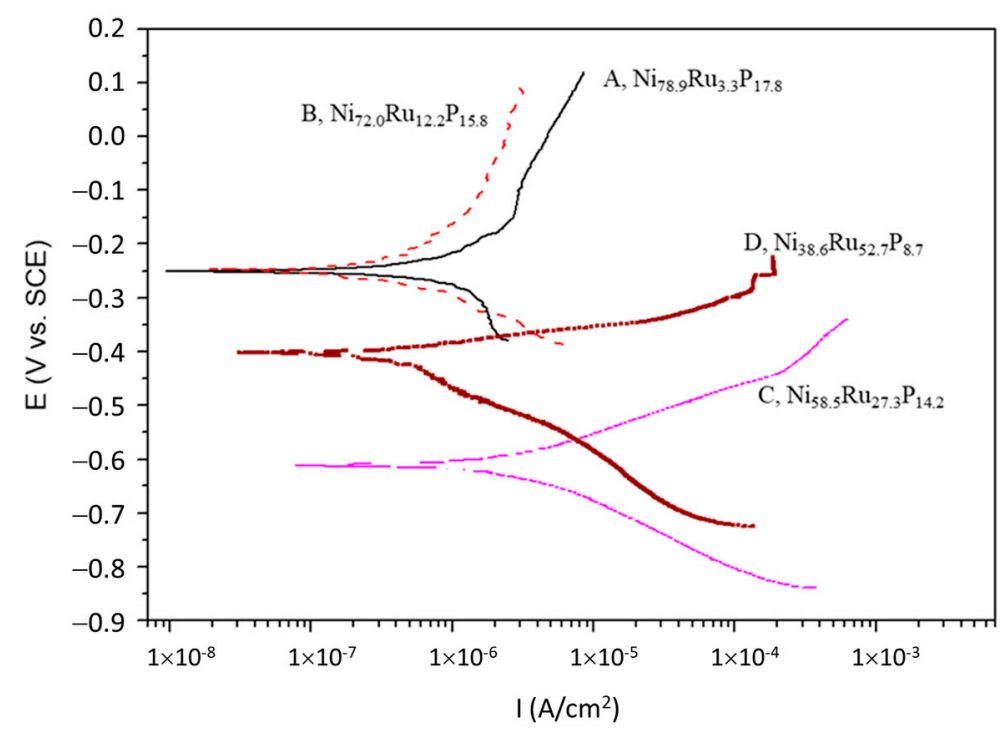

Figure 4. The potentiodynamic polarization curves of the as-deposited $\mathrm{Ni}-\mathrm{Ru}-\mathrm{P}$ coatings.

Table 3. The $E_{\text {corr }}$ and $I_{\text {corr }}$ of the Ni-Ru-P coatings in as-deposited and annealed states.

\begin{tabular}{|c|c|c|c|}
\hline Coating Systems & Process Condition & $E_{\text {corr }}(\mathrm{V}$ vs. SCE $)$ & $I_{\text {corr }}\left(\mathrm{Amps} / \mathrm{cm}^{2}\right)$ \\
\hline \multirow{3}{*}{$\mathrm{A}, \mathrm{Ni}_{78.9} \mathrm{Ru}_{3.3} \mathrm{P}_{17.8}$} & $200^{\circ} \mathrm{C}$ as-deposited & -0.25 & $6.04 \times 10^{-6}$ \\
\hline & $475^{\circ} \mathrm{C}$ annealed & -0.54 & $3.21 \times 10^{-6}$ \\
\hline & $550{ }^{\circ} \mathrm{C}$ annealed & -0.55 & $3.55 \times 10^{-6}$ \\
\hline \multirow{3}{*}{$\mathrm{B}, \mathrm{Ni}_{72.0} \mathrm{Ru}_{12.2} \mathrm{P}_{15.8}$} & $200^{\circ} \mathrm{C}$ as-deposited & -0.25 & $2.22 \times 10^{-6}$ \\
\hline & $475^{\circ} \mathrm{C}$ annealed & -0.54 & $4.22 \times 10^{-6}$ \\
\hline & $550^{\circ} \mathrm{C}$ annealed & -0.54 & $4.56 \times 10^{-6}$ \\
\hline \multirow{3}{*}{$\mathrm{C}, \mathrm{Ni}_{58.5} \mathrm{Ru}_{27.3} \mathrm{P}_{14.2}$} & $200^{\circ} \mathrm{C}$ as-deposited & -0.61 & $2.96 \times 10^{-6}$ \\
\hline & $475^{\circ} \mathrm{C}$ annealed & -0.55 & $5.61 \times 10^{-6}$ \\
\hline & $550{ }^{\circ} \mathrm{C}$ annealed & -0.53 & $8.44 \times 10^{-6}$ \\
\hline \multirow{2}{*}{$\mathrm{D}, \mathrm{Ni}_{38.6} \mathrm{Ru}_{52.7} \mathrm{P}_{8.7}$} & $200^{\circ} \mathrm{C}$ as-deposited & -0.40 & $3.04 \times 10^{-6}$ \\
\hline & $550^{\circ} \mathrm{C}$ annealed & -0.59 & $6.95 \times 10^{-6}$ \\
\hline
\end{tabular}

It seems that the variation in $\mathrm{Ru}$ content is responsible for the changes in $E_{\text {corr }}$ values between sample A, B, and C. Yet P content would be the key to this issue. With high P content over 9 at.\%, 
the Ni-P-based alloy coatings tend to be nanocrystalline. A higher P content may further induce an amorphous structure for the Ni-P-based coatings. Since those coatings in this study possess a major $\mathrm{Ni}$ amorphous/nanocrystalline microstructure, the decrease in $\mathrm{P}$ content in the coatings is responsible for the degeneration of $E_{\text {corr }}$ for samples $\mathrm{A}, \mathrm{B}$, and $\mathrm{C}$. When the Ru content further increases to 52.7 at. $\%$ in the Ni-Ru-P coatings, the $E_{\text {corr }}$ is elevated to $-0.40 \mathrm{~V}$ (which is still more active than $\mathrm{A}$ and $\mathrm{B}$ coatings). It should be noted that the crystallized $\mathrm{Ni}, \mathrm{Ru}$, and $\mathrm{Ru}_{2} \mathrm{P}$ phases are present for the $\mathrm{Ni}_{38.6} \mathrm{Ru}_{52.7} \mathrm{P}_{8.7}$ coating. Another fact is that the chemically inert Ru dominates in the $\mathrm{Ni}_{38.6} \mathrm{Ru}_{52.7} \mathrm{P}_{8.7}$ coating. Moreover, it has been demonstrated that a medium $\mathrm{P}$ content around 8 at.\% is beneficial for better corrosion resistance in Ni-P alloy system [27]. Thus a more positive potential for the $\mathrm{Ni}_{38.6} \mathrm{Ru}_{52.7} \mathrm{P}_{8.7}$ film is expected as compared to the $\mathrm{Ni}_{58.5} \mathrm{Ru}_{27.3} \mathrm{P}_{14.2}$ coating.

After annealing processes at 475 or $550{ }^{\circ} \mathrm{C}$ for $3 \mathrm{~h}$, the $E_{\text {corr }}$ values for all coatings drop to -0.59 to $-0.53 \mathrm{~V}$. The corrosion current density for all the coatings keeps at an order of $10^{-6} \mathrm{Amp} / \mathrm{cm}^{2}$. The degeneration of corrosion potential in coatings $\mathrm{A}$ and $\mathrm{B}$ is significant. This is due to the phase transformation of the amorphous/nanocrystalline structure to a crystallized $\mathrm{Ni}(\mathrm{Ru})$ with $\mathrm{Ni}_{x} \mathrm{P}_{y}$ compounds, as illustrated in Figures 1 and 2. The ternary amorphous Ni-P-based coating exhibited a higher corrosion resistance than its crystallized form. The crystallized structure provides better opportunities for corrosion solution to go along the grain boundaries and defects. A lower corrosion resistance is thus reasonable for the annealed $\mathrm{Ni}-\mathrm{Ru}-\mathrm{P}$ films. Nevertheless, it has been proved that the $\mathrm{Ni}-\mathrm{P}$ and its composite coatings present the a relatively noble corrosion potential due to microstructure change when annealed at 400 and $500{ }^{\circ} \mathrm{C}$ [14]. In the present study, the $I_{\text {corr }}$ values deduced for the annealed samples are within the same order of $10^{-6} \mathrm{Amp} / \mathrm{cm}^{2}$ for as-deposited ones, implying the corrosion currents for the $\mathrm{Ni}-\mathrm{Ru}-\mathrm{P}$ films do not increase significantly after heat treatment.

The corroded surface images were analyzed to determine the corrosion mechanism for the $\mathrm{Ni}-\mathrm{Ru}-\mathrm{P}$ coatings. The as-deposited Ni-Ru-P films remain a smooth and dense feature, similar to that in Figure $3 \mathrm{a}$, after corrosion in $3.5 \mathrm{M} \mathrm{NaCl}$ solution. On the other hand, the pitting corrosion behavior is found for the 475 and $550{ }^{\circ} \mathrm{C}$ annealed coatings, as illustrated in Figure 5. For $475{ }^{\circ} \mathrm{C}$ annealed $\mathrm{C}, \mathrm{Ni}_{58.5} \mathrm{Ru}_{27.3} \mathrm{P}_{14.2}$ coating, etching pits with diameter of approximately 40 to $50 \mathrm{~nm}$ are observed. The pitting corrosion phenomenon is also found for the $550{ }^{\circ} \mathrm{C}$ annealed $\mathrm{D}, \mathrm{Ni}_{38.6} \mathrm{Ru}_{52.7} \mathrm{P}_{8.7}$ coating. Intense pitting corrosion with large pit size over $100 \mathrm{~nm}$ is shown for annealed coatings with less $\mathrm{Ru}$ contents, as illustrated in Figure 5c. The explanation can be two-fold. Firstly the structure of the low Ru content coatings comprises of dominated $\mathrm{Ni}$ phase and $\mathrm{Ni}_{x} \mathrm{P}_{y}$ compounds. The crystallized Ni microstructure is more easily to be corroded away since more grain boundaries are present after annealing. Secondly, lower Ru content decreases the chemical inertness of the Ni-Ru-P films intrinsically. As a consequence, the annealed coatings with less $\mathrm{Ru}$ content, like $\mathrm{A}, \mathrm{Ni}_{78.9} \mathrm{Ru}_{3.3} \mathrm{P}_{17.8}$ and $\mathrm{B}, \mathrm{Ni}_{72.0} \mathrm{Ru}_{12.2} \mathrm{P}_{15.8}$ films, exhibit severe pitting and significant drop in corrosion resistance.
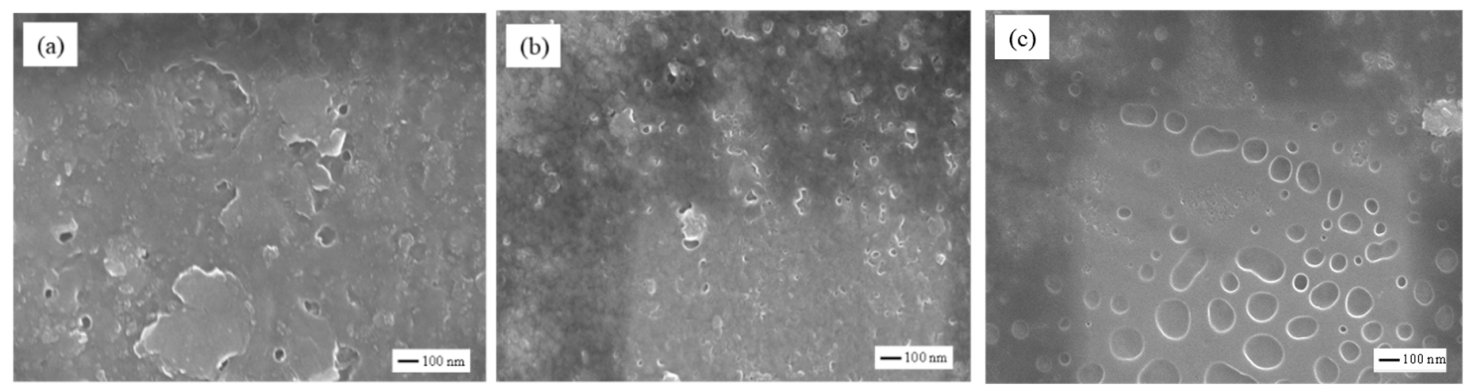

Figure 5. The FE-SEM surface images of corroded (a) $475{ }^{\circ} \mathrm{C}$ annealed $\mathrm{C}, \mathrm{Ni}_{58.5} \mathrm{Ru}_{27.3} \mathrm{P}_{14.2}$, (b) $475{ }^{\circ} \mathrm{C}$ annealed $\mathrm{D}, \mathrm{Ni}_{38.6} \mathrm{Ru}_{52.7} \mathrm{P}_{8.7}$ and (c) $550{ }^{\circ} \mathrm{C}$ annealed $\mathrm{B}, \mathrm{Ni}_{72.0} \mathrm{Ru}_{12.2} \mathrm{P}_{15.8}$ coatings.

\section{Conclusions}

$\mathrm{Ni}-\mathrm{Ru}-\mathrm{P}$ alloy coatings with Ru contents from 3.3 to 52.7 at. $\%$ are fabricated by magnetron dual-gun co-sputtering technique with target input power control. The as-deposited $\mathrm{Ni}-\mathrm{Ru}-\mathrm{P}$ coatings with $\mathrm{Ru}$ 
concentration below 27.3 at.\% show an amorphous/nanocrystalline microstructure. The high Ru-content $\mathrm{Ni}_{38.6} \mathrm{Ru}_{52.7} \mathrm{P}_{8.7}$ coating, on the other hand, exhibits crystallized $\mathrm{Ni}, \mathrm{Ru}$, and $\mathrm{Ru}_{2} \mathrm{P}$ mixed phases in its as-fabricated state. The amorphous/nanocrystalline $\mathrm{Ni}-\mathrm{Ru}-\mathrm{P}$ thin films transform into $\mathrm{Ni}(\mathrm{Ru})$ and $\mathrm{Ni}_{x} \mathrm{P}_{y}$ crystallized phases under annealing, while the high $\mathrm{Ru}$-content $\mathrm{Ni}_{38.6} \mathrm{Ru}_{52.7} \mathrm{P}_{8.7}$ coating possesses a stable mixed-phase structure against heat treatment. The as-fabricated $\mathrm{Ni}-\mathrm{Ru}-\mathrm{P}$ films show an increased hardness from 7.2 to $10.4 \mathrm{GPa}$ with the Ru contents. Due to phase transformation, the annealed films possess an increased surface hardness. The highest film hardness of $12.1 \mathrm{GPa}$ is found for the $550{ }^{\circ} \mathrm{C}$ heat-treated high $\mathrm{Ru}$-content $\mathrm{Ni}_{38.6} \mathrm{Ru}_{52.7} \mathrm{P}_{8.7}$ coating owing to its stable mixed-phase structure. For the as-deposited coatings with an amorphous/nanocrystalline feature, the decrease in $\mathrm{P}$ content is responsible for the decrease in corrosion potential. The degeneration of $E_{\mathrm{corr}}$ for the annealed $\mathrm{Ni}-\mathrm{Ru}-\mathrm{P}$ coatings is attributed to the crystallized phases of $\mathrm{Ni}$ and $\mathrm{Ni}_{x} \mathrm{P}_{y}$ compounds. All the annealed $\mathrm{Ni}-\mathrm{Ru}-\mathrm{P}$ coatings show a pitting corrosion feature in a $3.5 \mathrm{M} \mathrm{NaCl}$ solution. Severe localized pitting on $550{ }^{\circ} \mathrm{C}$ annealed low $\mathrm{Ru}$ content $\mathrm{Ni}-\mathrm{Ru}-\mathrm{P}$ coatings is observed. The development of $\mathrm{Ni}(\mathrm{Ru})$ and $\mathrm{Ni}_{x} \mathrm{P}_{y}$ crystallized phases during annealing is responsible for the degeneration of corrosion resistance.

Author Contributions: Conceptualization, F.-B.W.; methodology, Y.-C.H.; investigation, Y.-C.H.; data curation, Y.-C.H.; writing—original draft preparation, Y.-C.H.; writing—review and editing, F.-B.W.; visualization, Y.-C.H.; supervision, F.-B.W.; funding acquisition, F.-B.W. All authors have read and agreed to the published version of the manuscript.

Funding: This research was funded by Ministry of Science and Technology, Taiwan, under contracts Nos. NSC-98-2221-E-239-009-MY3, MOST-107-2221-E-239-004-MY3, MOST-107-2218-E-011-017 and MOST-108-2218-E-011-008.

Acknowledgments: Technical support and constructive discussion from S.Y. Tsai and J.G. Duh in the Field-Emission Electron Probe Microanalysis, FE-EPMA, Lab, Instrumental Center, National Tsing Hua University are highly acknowledged.

Conflicts of Interest: The authors declare no conflict of interest.

\section{References}

1. Loto, C.A. Electroless nickel plating-A review. Silicon 2016, 8, 177-186. [CrossRef]

2. Garcia, I.; Fransaer, J.; Celis, J.P. Electrodeposition and sliding wear resistance of nickel composite coatings containing micron and submicron SiC particles. Surf. Coat. Technol. 2001, 148, 171-178. [CrossRef]

3. Chiba, Y.; Ornura, T.; Ichimura, H. Wear resistance of arc ion-plated chromium nitride coatings. J. Mater. Res. 1993, 8, 1109-1115. [CrossRef]

4. Lin, K.L.; Hwang, J.W. Effect of thiourea and lead acetate on the deposition of electroless nickel. Mater. Chem. Phys. 2002, 76, 204-211. [CrossRef]

5. Keong, K.G.; Sha, W.; Malinov, S. Hardness evolution of electroless nickel-phosphorus deposits with thermal processing. Surf. Coat. Technol. 2003, 168, 263-274. [CrossRef]

6. Skulev, H.; Malinov, S.; Sha, W.; Basheer, P.A.M. Microstructural and mechanical properties of nickel-base plasma sprayed coatings on steel and cast iron substrates. Surf. Coat. Technol. 2005, 197, 177-184. [CrossRef]

7. Tasi, Y.Y.; Wu, F.B.; Chen, Y.I.; Peng, P.J.; Duh, J.G.; Tsai, S.Y. Thermal stability and mechanical properties of Ni-W-P electroless deposits. Surf. Coat. Technol. 2001, 146, 502-507.

8. Wu, F.B.; Tien, S.K.; Tsai, Y.Z.; Duh, J.G. Phase transformation and hardness of the Ni-P-Al ternary coatings under thermal annealing. Thin Solid Films 2006, 494, 151-154. [CrossRef]

9. Chen, W.Y.; Duh, J.G. Thermal stability of sputtered Ni-P and Ni-P-Cr coatings during cycling test and annealing treatment. Surf. Coat. Technol. 2004, 177, 222-226. [CrossRef]

10. Chou, Y.H.; Sung, Y.; Liu, Y.M.; Pu, N.W.; Ger, M.D. Amorphous Ni-Mo-P diffusion barrier deposited by non-isothermal deposition. Surf. Coat. Technol. 2009, 203, 1020-1026. [CrossRef]

11. Armyanov, S.; Steenhaut, O.; Krasteva, N.; Geogeorgieva, J.; Delplancke, J.-L.; Winand, R.; Vereecken, J. Auger electron spectroscopy element profiles and interface with substrates of electroless deposited ternary alloys. J. Electrochem. Soc. 1996, 143, 3692. [CrossRef]

12. Chang, Y.C.; Duh, J.G.; Chen, Y.I. Fabrication and crystallization behaviors of sputtered Ni-Cu-P films on tool steel. Surf. Coat. Technol. 2001, 139, 233-243. [CrossRef] 
13. Liu, Y.; Zhao, Q. Study of electroless Ni-Cu-P coatings and their anti-corrosion properties. Appl. Surf. Sci. 2004, 228, 57-62. [CrossRef]

14. León, C.; García-Ochoa, E.; García-Guerra, J.; González-Sánchez, J. Annealing temperature effect on the corrosion parameters of autocatalytically produced $\mathrm{Ni}-\mathrm{P}$ and $\mathrm{Ni}-\mathrm{P}-\mathrm{Al}_{2} \mathrm{O}_{3}$ coatings in artificial seawater. Surf. Coat. Technol. 2010, 205, 2425-2431. [CrossRef]

15. Nova'k, M.; Vojte ch, D.; Vı'tu, T. Influence of heat treatment on tribological properties of electroless Ni-P and $\mathrm{Ni}-\mathrm{P}-\mathrm{Al}_{2} \mathrm{O}_{3}$ coatings on Al-Si casting alloy. Appl. Surf. Sci. 2010, 256, 2956-2960. [CrossRef]

16. Yang, Z.; Xu, H.; Shi, Y.L.; Li, M.K.; Huang, Y.; Li, H.L. The fabrication and corrosion behavior of electroless Ni-P-carbon nanotube composite coatings. Mater. Res. Bull. 2005, 40, 1001-1009. [CrossRef]

17. Zarebidaki, A.; Allahkaram, S.-R. Effect of surfactant on the fabrication and characterization of Ni-P-CNT composite coatings. J. Alloy Compd. 2011, 509, 1836-1840. [CrossRef]

18. Zhao, G.; Wang, R.; Liu, S.; Wang, T.; Wu, D.; Zhang, Y.; Chen, J.; Zou, Y. Microstructure analysis of element $\mathrm{W}$ in improving the Ni-P deposit thermal stability. J. Mater. Res. Technol. 2020, 9, 5474-5486. [CrossRef]

19. Wu, F.B.; Chen, Y.I.; Peng, P.J.; Tsai, Y.Y.; Duh, J.G. Fabrication, thermal stability and microhardness of sputtered Ni-P-W coating. Surf. Coat. Technol. 2002, 150, 232-238. [CrossRef]

20. Marzo, F.F.; Alberro, M.; Manso, A.P.; Garikano, X.; Alegre, C.; Montiel, M.; Lozano, A.; Barreras, F. Evaluation of the corrosion resistance of $\mathrm{Ni}(\mathrm{P}) \mathrm{Cr}$ coatings for bipolar plates by electrochemical impedance spectroscopy. Int. J. Hydrogen Energy 2020, in press. [CrossRef]

21. Wu, F.B.; Tien, S.K.; Duh, J.G.; Wang, J.H. Surface characteristics of electroless and sputtered Ni-P-W alloy coatings. Surf. Coat. Technol. 2003, 166, 60-66. [CrossRef]

22. Wu, F.B.; Su, Y.M.; Tsai, Y.Z.; Duh, J.G. Fabrication and characterization of the Ni-P-Al-W multicomponent coatings. Surf. Coat. Technol. 2007, 202, 762-767. [CrossRef]

23. Kweon, D.H.; Okyay, M.S.; Kim, S.J.; Jeon, J.P.; Noh, H.J.; Park, N.J.; Mahmood, J.; Baek, J.B. Ruthenium anchored on carbon nanotube electrocatalyst for hydrogen production with enhanced Faradaic efficiency. Nat. Commun. 2020, 11, 1-10. [CrossRef] [PubMed]

24. Kotsiras, A.; Kalaitzidou, I.; Grigoriou, D.; Symillidis, A.; Makri, M.; Katsaounis, A.; Vayenas, C.G. Electrochemical promotion of nanodispersed $\mathrm{Ru}-\mathrm{Co}$ catalysts for the hydrogenation of $\mathrm{CO}_{2}$. Appl. Catal. B Environ. 2018, 232, 60-68. [CrossRef]

25. Shin, J.; Waheed, A.; Winkenwerder, W.A.; Kim, H.W.; Agapiou, K.; Jones, R.A.; Hwang, G.S.; Ekerdt, J.G. Chemical vapor deposition of amorphous ruthenium-phosphorus alloy films. Thin Solid Films 2007, 515, 5298-5307. [CrossRef]

26. Hugh, B.; Hiroaki, O. Alloy Phase Diagrams. In ASM Handbook; ASM International: Almere, the Netherlands, 2016; Volume 3.

27. Singh, D.D.N.; Ghosh, R. Electroless nickel-phosphorus coatings to protect steel reinforcement bars from chloride induced corrosion. Surf. Coat. Technol. 2006, 201, 90-101. [CrossRef] 